\title{
Mountain Biodiversity: Reason Behind its High Diversity and its Change with Time
}

\author{
Bhawana K.C. ${ }^{1}$
}

\begin{abstract}
Mountain "islands in the sky" covering one fourth of Earth's surface provide goods and services to about half of humanity, with nearly half of all 34 world's biodiversity hotspot concentrated in it. Although retaining inherently greater biodiversity, mountains are facing loss of these natural assets due to various human induced causes of which few to name are deforestation, uphill expansion of agriculture etc. With integrated knowledge of mountain biodiversity change in the pathway of time and threatening factors of mountain biodiversity, we can broaden our horizon of knowledge which can be a milestone in sustainable conservation of biodiversity. This is a review article which endeavors to identify the reasons behind high mountain biodiversity and its increasing vulnerability with time.

"आकाशको प्रायद्धिप" जस्तै गरी अवस्थित हिमालले पृथ्वीको सतहको एक चौथाई भू-भाग ओगटेको छ तर करिव आधा जति मानव जीवनको लागि वस्तु तथा सेवा उपलव्ध गराउँछन् र तिनै हिमालहरुमा आधाजसो जैविक विविधताका मुख्य केन्द्रहरु रहेका छन् । यद्यपि तिनै हिमालहरुले आफ्नो प्राकृतिक धनहरु गुमाउँदै छन, वन फँडानी, भिरालो कृषि प्रणाली जस्ता मानवीय कारणहरुले गर्दा। समय अनुसार हिमाली जैविक विविधताको हानीलाई रोक्न एकिकृत ज्ञान र विषयवस्तुको गहिराईसम्म पुगेर कार्य गर्न सके ति विविधताको दिगो संरक्षण गर्न सकिन्छ। यस लेखको मुख्य उद्धेश्य हिमाली जैविक विविधताका कारण तथा समय अनुसार यसले बेहोर्नुपरेको खतराहरुको बारेमा तथ्यपरक रुपमा प्रस्तुत गर्नु हो।
\end{abstract}

Key Words: Mountain, Biodiversity, Ecosystem, Temporal change

\section{Introduction}

Mountains "islands in the sky" cover almost $24 \%$ of the surface area of the earth and about $12 \%$ of the global human population ( 6.8 billions ) live with this astounding series of rugged valleys and peaks which provide goods and services to about half of humanity (Messerli and Ives, 1997). The mountains are home to a rich array of fauna and flora and are the source of water and other ecosystem services, more perhaps than we can imagine. For the mountain communities, mountain resources are particularly important as it contributes to their subsistence, their welfare and to the improvement of their livelihood. Mountains are the source of inspiration and recreation for a crowded world but they also serve as the "Water Tower of the World", with a growing emphasis globally on water resource issued, this function is invaluable for human being. That is why mountain has ecological, aesthetic and socioeconomic significance, not only for those living in the mountain areas but also for people living beyond.

${ }^{1}$ Kathmandu Forestry College, Kathmandu, Nepal, Email: bhawanakc@gmail.com 
The biological resources are the physical manifestation of the globe's diversity, which simply states the variety and variability among living organisms and the ecological complexes in which they occur. Biodiversity refers to combination of life, forms and their interactions. These interactions occur at different levels (genetic, species and ecosystem) and depend upon the physical environment. It is essentially everywhere, ubiquitous on the earth surface and in every drop of water, which is the foundation to ecosystem to which human wellbeing is intimately linked. Mountains occur on all continents, in all latitude, zones and within all the world's principal biome types - from hyper-arid hot desert and tropical forest to arid polar icecaps - and support a wide variety of ecosystems. Mountain resources are important to mountain communities for their contribution to subsistence, welfare and improvement of livelihood. Lowland people also depend on mountain environment for a wide range of environmental services including water, energy, timber, biodiversity maintenance, and opportunities for recreation and spiritual renewal. Many mountain ecosystems are host to higher species richness and levels of endemism than adjacent lowlands. Mountains at lower altitudes can support exceptional biodiversity, due to compression of a wide range of ecosystems into a relatively short distance and often provide islands of suitable habitat, isolated from unfavorable surrounding lowlands. Mountain areas have also acted as refuges from environmental change and are also characterized by moderate disturbances such as landslides, avalanches and grazing, which often increase biological richness and habitat diversity. Though species, genetic and ecosystem diversity per unit land area in mountain is often greater than in the lowland, new pressure have led to mountain ecosystem being declared one of the Earth's most threatened region. The UNCED (United Nation Conference on Environment and Development) in June 1992 in Rio De Janerio states "Mountain environment are essential to survival of global ecosystem, many of them are experiencing degradation in terms of accelerated erosion, landslides, and rapid loss of habitat and genetic diversity. Hence, proper management of mountain resources and socio-economic development of the people deserves immediate action".

The Eastern Himalayas which harbor a globally outstanding biological diversity, is at the crossroads of two continental plates represented by two biogeographical realms (the lowland Indo-Malayan Realm and to the North, the elevated Palearctic Realm) falls between $82.70^{\circ} \mathrm{E}-$ $100.31^{\circ} \mathrm{E}$ latitude and $21.95^{\circ} \mathrm{N}-29.45^{\circ} \mathrm{N}$ longitude which extends from the deep gorge of the Kali Gandaki river eastward through central Nepal to Northern Myanmar. It's hotspot includes four global 200 ecoregions, critical landscapes of international biological importance, four World Heritage Sites, two endemic bird areas, and several global centres for plant diversity. The rugged and largely inaccessible landscape of the Eastern Himalayas harbor a staggering 10,000 plant species, 300 mammal species, 977 bird species, 176 reptiles, 105 amphibians and 269 types of freshwater fishes. Only $25 \%$ of the original habitats in the region remain intact and 163 species that live in the Eastern Himalayas are considered globally threatened. At least 353 new species have been discovered in the Eastern Himalayas between 
1998 and 2008, equating to an average of 35 new species found every year for the last 10 years. The discoveries include 242 plants, 16 amphibians, 16 reptiles, 14 fishes, 2 birds and 2 mammals, and at least 61 new invertebrates.

\section{Reasons behind high diversity of mountain region}

Biodiversity is high in mountain regions because of the varied micro-climates and ecological conditions which give rise to wide range of habitats. Altitudinal and ecological zones provide plants with different exposures over short distances. The topography itself is a varied and a fragmented mosaic of habitats or genetic 'islands in the sky', yielding a high 'geo-diversity' offering a multitude of ecological niches. Lastly, mountains have been less altered by human because of the harsher climate and logistical difficulties inherent in the mountain region. Therefore, mountains are not only 'islands in the sky' but also 'islands of biodiversity'. On a global scale, whole mountain systems clearly exceed the species diversity of the lowlands (Barthlott et al. 1996).

The example of different countries given below shows that the species richness in mountain region is higher in comparison to lowland as the percentage of species found in these areas are extremely higher in relation to the percentage of the area they occupied.

Table 1: Per unit land area of mountain biota are biologically richer than most lowlands. (There examples of plant species):

\begin{tabular}{|l|c|c|c|c|}
\hline \multicolumn{1}{|c|}{ Country } & $\begin{array}{c}\text { Total number } \\
\text { of species }\end{array}$ & $\begin{array}{c}\text { Species found } \\
\text { above } \\
\text { treeline }\end{array}$ & $\begin{array}{c}\text { Species exclusively } \\
\text { found above } \\
\text { treeline (as \% of } \\
\text { total) }\end{array}$ & $\begin{array}{c}\text { Area above treeline } \\
\text { (\% of total) incl. ice \& } \\
\text { rock }\end{array}$ \\
\hline Chile & 4000 & 1900 & $870(22 \%)$ & $19 \%$ \\
\hline New Zealand & 2200 & 620 & $210(10 \%)$ & $10 \%$ \\
\hline Switzerland & 2570 & 1280 & $570(22 \%)$ & $23 \%$ \\
\hline
\end{tabular}

Source: Mountains Biodiversity Matters, GMBA, 2001

One ever valid foundation of biodiversity conservation is ethics: "every species has a right to exist and flourish" which does not need any scientific justification. Human also create biodiversity by domesticating plants and animals, adding a cultural element to biological richness. On the other hand, science is able to add further justifications which neither devalue nor replace the aesthetic value, the ethical and cultural motives like the motives of ecosystem functioning (such as productivity, nutrient, carbon and water cycle, soil protection and erosion control, and biotic interactions) and the economic motive (such as safety from erosion, clean water supplies, genetic resources) (Korner 2004), insurance principle etc.

Nepal, comprising only $0.1 \%$ of total global land area and having more than $70 \%$ mountainous area, remarkable share on global biodiversity regime. Most of the causes behind these are 
altitudinal range and diverse topography. An overview of species richness in Nepal is shown in following table.

Table 2: Species richness in Nepal

\begin{tabular}{|c|l|c|c|c|}
\hline \multirow{2}{*}{ S.N } & \multirow{2}{*}{ Group of organism } & \multicolumn{2}{|c|}{ Number of species } & \multirow{2}{*}{$\begin{array}{c}\text { Nepal } \\
\text { representative }\end{array}$} \\
\cline { 3 - 4 } & & globally & Nepal & - \\
\hline 1 & Bacteria & $3000-4000$ & - & 2.3 \\
\hline 2 & Lichens & 20000 & 465 & 2.4 \\
\hline 3 & Fungi & 69000 & 1822 & 2.6 \\
\hline 4 & Algae & 26000 & 687 & 5.1 \\
\hline 5 & Bryophytes & 16600 & 853 & 3.4 \\
\hline 6 & Pteridophytes & 11300 & 380 & 5.1 \\
\hline 7 & Gymnosperms & 529 & 28 & 2.7 \\
\hline 8 & Angiosperms & 220000 & 5856 & 1.4 \\
\hline 9 & Platyhelminthis & 12200 & 168 & 0.2 \\
\hline 10 & Spiders & 73400 & 144 & 2.6 \\
\hline 11 & Butterflies \& moths & 112000 & 2253 & 0.7 \\
\hline 12 & Other insects & 751000 & 5052 & 1.0 \\
\hline 13 & Fishes & 18150 & 182 & 1.0 \\
\hline 14 & Amphibians & 4184 & 43 & 1.6 \\
\hline 15 & Reptiles & 6300 & 100 & 9.3 \\
\hline 16 & Birds & 9040 & 852 & 4.5 \\
\hline 17 & Mammals & 4000 & 181 & \\
\hline
\end{tabular}

Source: Nepal Biodiversity Strategy, 2002

\section{Natural drivers of biological richness at highland ecology}

* The compression of climatic zones along elevation gradient causes mountain biota to represent hotspots of biological richness. At very high elevation biodiversity diminishes gradually but so does land area, leading to very high biodiversity which often exceeds those of lower elevation.

Exposure, steepness of slope, variation of substrate and microclimate over short distances create a multitude of microhabitat, each nesting a different set of organisms which again permit aggregation of rather diverse biota over short distances. Biodiversity changes along with change in gravity and also with grazing pattern (as grazing pattern creates the structure by patchy disturbance, dung deposition and food preference) and hence, adding to the biological richness of many high elevation biota. 
- Mountain range/peaks often represents isolated archipelagoes of peculiar life conditions explaining their richness in endemic species found only at one location worldwide. Endemism also reflect geological and climatological history.

* Mountains that bridge between biogeographic zones are richer than isolated ones.

* Within a given mountain, transition zone between elevational belts of vegetations are particularly rich in taxa (e.g. forest-alpine transition)

* Soil with their biota not only store and recycle nutrient, but also hold moisture for dry period and provide mechanical holds for roots where their development and structure depends on topography and age. On slope, there is no vegetation without soil and no soil without vegetation. Only vegetation can secure the soil against gravity and once the soil is eroded the ecosystem is gone. Thus, the soil integrity is one of the driver of highland biota along with the vegetation which is the key factor in soil preservation.

\section{Causes of changes in mountain biodiversity}

Despite their apparent remoteness and inaccessibility the mountain have not been spared human induced biodiversity loss. Deforestation and habitat alteration cause highly diverse natural ecosystem to become less diverse, often monoculture agro ecosystem has resulted in the extensive reduction of biological species in the region. Change in land use, uphill expansion of agriculture and settlements, logging for timber and fuel wood, replacement by highland pasture, overgrazing, etc are the human activities threatening to mountain forest which are among the most biologically diverse biota. In addition to habitat loss and degradation poaching is a serious problem in Himalayan region.

Globalisation (describes an ongoing process by which regional economies, societies and cultures have become integrated through globe-spanning networks of exchange) and climate change are threatening biodiversity even in the remote part of the mountains as mountain environment respond strongly even to small changes in temperature because of their vertical (altitudinal) dimensions create gradients of temperature precipitation and solar radiations. In recent decades, easier access through road construction, population pressure, migration and exposure to the wider world have led to the collapse of traditional modes of land and resource use in many mountain areas worldwide; and in addition mining, industrialization and tourism have led to pressures on biodiversity which are causing substantial and largely irreversible loss in the diversity of life. Movements of people and goods have also triggered further spread of invasive species. The fourth Assessment report of the IPCC (InterGovernmental Panel on Climate Change) concluded that changes in the atmosphere, oceans, glaciers, and ice caps demonstrate that the planet is warming. The data available for the Eastern Himalayas shows that there is a definite warming trend at higher altitude and that 
areas at altitudes above $4000 \mathrm{~m}$ seem to be experiencing the greatest warming trend. The warming trend observed ranges from 0.01 to 0.06 degree Celsius per year and the mean temperature is expected to increase by 2.9 degree Celsius by the middle of the century. Climate change is likely to have both positive and negative effects on biodiversity, although the negative effects may prevail overall which is affecting the ecosystem services by affecting forest type and area, primary productivity, species populations and migration, the occurrence of pests and diseases, forest regeneration, etc. Global warming largely affects mountain biodiversity by reducing available land area for organisms adapted to the cold. The pace of plant species moving uphill is quite high increasing the total number of species in the upper belt in the short term but outcompeting species rare or those adapted to the cold in the long run. Plant invasion into higher mountain areas may be promoted by climate warming. As rain pattern change, the unique plants that grow in their harsh environment may die out, threatening the animals and insects that depend on them and the livelihood of the mountain people who use them.

From the other side of the coin, mountains are in a particularly good situation in comparison to any other environment as the temperature increases with increase in the altitude. At least for slowly-migrating organisms such as plants mountains are in fact the best places on earth to cope with climatic warming because for many (though not all), there are cool escape hatches at short distances away for those that cannot stand the 'new heat'. Lowland taxa must either 'find' a mountain or adapt. The likelihood that this will happen is much less for lowland taxa than for taxa inhabiting mountain slopes. Nevertheless, the land area shrinks, and what might not be a problem for tiny plants might lead to drastic declines in population of large territorial animals. Below figure summarizes the various migratory options plants and animals have in a mountain landscape.

Fig 1: A schematic presentation of migration of organisms in climatic warming

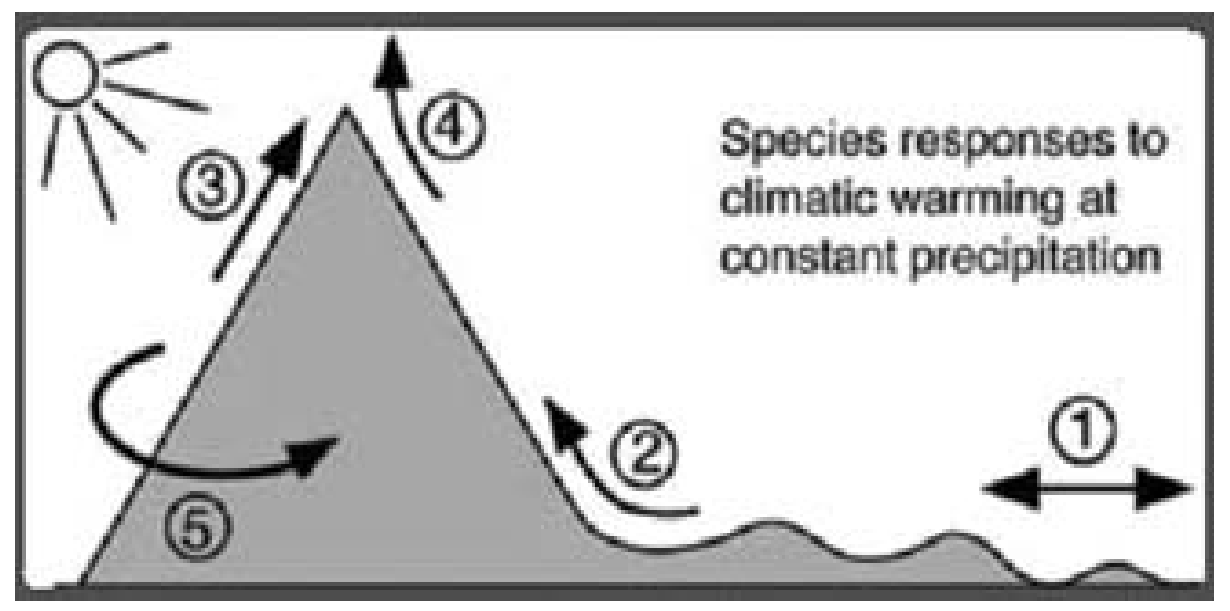

Source: ICIMOD, 2009 
1. Lowland species, lacking close distance escapes from too warm conditions

2. Foothill species migrating upslope

3. High-elevation species migrating towards summit regions

4. Summit species with no upslope escape but increasing competition from immigrants from lower elevation

5. Short distance escapes in highland taxa using micro-habitat diversity in rugged terrain, changing community mosaics at a given elevation

\section{Change in mountain biodiversity with time}

Plants and animals, even far from human habitation, are now endangered due to global warming, resulting from increasing concentrations of carbon dioxide released into the atmosphere through different human activities like burning of fossil fuels, deforestation. The current research shows that the effect of climate change would have on 25 global "biodiversity hotspots", (Biodiversity hotspots are a biogeographic region with a significant reservoir of biodiversity that is threatened with destruction. Altogether there are 34 biodiversity hot spots each holding at least 1500 endemic plant species. Once it covered $15.7 \%$ of the Earth's surface but now it cover only $2.3 \%$ ) areas containing a large number of the world's species, and yet having suffered from considerable habitat loss. The considered areas cover less than $2 \%$ of the global landmass, but they account for some $44 \%$ of the plants and $35 \%$ of the world's vertebrate study animals. As predicted by many climatologists if the doubling of present carbon dioxide levels and resulting temperatures rises tremendously they could potentially eliminate 56,000 plant and 3,700 endemic vertebrate species in the 25 hotspot regions (Science for Environment Policy, 2006).

Table 3: Regional mean temperature trends for the period $1977-2000\left({ }^{\circ} \mathrm{C}\right.$ per year $)$

\begin{tabular}{|l|c|c|c|c|c|}
\hline \multicolumn{1}{|c|}{ Regions } & Seasonal & Annual & & & \\
\cline { 2 - 6 } & $\begin{array}{c}\text { Winter } \\
\text { (Dec-Feb) }\end{array}$ & $\begin{array}{c}\text { Pre-monsoon } \\
\text { (Mar-may) }\end{array}$ & $\begin{array}{c}\text { Monsoon } \\
\text { (Jun-Sep) }\end{array}$ & $\begin{array}{c}\text { Past-monsoon } \\
\text { (Oct-Nov) }\end{array}$ & \\
\hline $\begin{array}{l}\text { Trans- } \\
\text { Himalayas }\end{array}$ & 0.12 & 0.01 & 0.11 & 0.10 & 0.09 \\
\hline Himalayas & 0.09 & 0.05 & 0.06 & 0.08 & 0.06 \\
\hline $\begin{array}{l}\text { Middle } \\
\text { Mountains }\end{array}$ & 0.06 & 0.05 & 0.06 & 0.09 & 0.08 \\
\hline
\end{tabular}

Source: Shrestha and Devkota, 2008

The above data presents the regional mean temperature trends for the period 1977-2000 $\left({ }^{\circ} \mathrm{C}\right.$ per year) which shows that annual mean temperature is increasing at a rate of $0.04^{\circ} \mathrm{C} /$ $\operatorname{yr}\left(0.01-0.12^{\circ} \mathrm{Cyr}^{-1}\right)$ or higher that simply means there is undergoing warming trend. There is both negatively and positively relationship between the warming trend and biodiversity richness. The sufficient population of individual species may even face greater disaster and reach to level of extinct, in particular area, more over the currently threatening species may face tragedy due to consequences of climate change. 
Table 4: Listed major threatened species of 10 countries ranked by number of threatened species by IUCN Red List, 2008

\begin{tabular}{|c|c|c|c|c|c|c|c|c|c|}
\hline Country & Mammals & Birds & Reptiles & $\begin{array}{c}\text { Amphibian } \\
\text { s }\end{array}$ & fishes & Molluscs & $\begin{array}{c}\text { Other } \\
\text { invertebrates }\end{array}$ & Plants & Total \\
\hline Ecuador & 43 & 69 & 11 & 171 & 15 & 48 & 12 & 1839 & 2208 \\
\hline $\begin{array}{c}\text { United } \\
\text { States }\end{array}$ & 37 & 74 & 32 & 56 & 164 & 273 & 312 & 244 & 1192 \\
\hline Malaysia & 70 & 42 & 21 & 47 & 49 & 19 & 207 & 686 & 1141 \\
\hline Indonesia & 183 & 115 & 27 & 33 & 111 & 3 & 229 & 386 & 1086 \\
\hline Mexico & 100 & 54 & 95 & 211 & 114 & 5 & 57 & 261 & 897 \\
\hline China & 74 & 85 & 30 & 90 & 70 & 1 & 20 & 446 & 816 \\
\hline Australia & 57 & 49 & 38 & 48 & 84 & 175 & 282 & 55 & 788 \\
\hline Brazil & 82 & 122 & 22 & 30 & 64 & 21 & 15 & 382 & 738 \\
\hline India & 96 & 76 & 25 & 65 & 40 & 2 & 109 & 246 & 659 \\
\hline Colombia & 52 & 86 & 15 & 214 & 31 & 0 & 31 & 223 & 652 \\
\hline
\end{tabular}

Source: IUCN Red List, 2008

\section{Gaps to move to maintain mountain biodiversity}

Due to poor accessibility, low population density and lack of infrastructure has led to low rates of data collection and a general lack of reliable data for the mountain region.

Old databases have a great value for detecting long-term trend in biodiversity. Site revisitation and long term monitoring of permanent plots seems to be the most promising tool for detecting changes in vegetation. However, the indicators of environmental change in mountain region can be

- Cryospheric indicators related to snow cover, glaciers, permafrost and solifluction processes.

- Terrestrial ecosystem, particularly mountain plant communities and soil.

- Freshwater ecosystem, in particular high mountain streams and lakes.

- Watershed hydrology, i.e. water balance component of high mountain watershed, headwater basins.

Environmental changes often affected species abundance and distribution more than they determine the presence or absence of taxa. However, reduced abundance and habitat fragmentation may lead to species extinction in long run (Inbreeding depression).

* Climatic warming will reduce available land area for cold adapted organism (summit trap phenomenon), unless suitable microclimate for migration are available, many species are likely to become extinct. 
Top reasons to promote conservation and sustainable use of mountain ecosystems

1. Mountains harbour an extremely high biological diversity.

2. Half of the human population depends on mountains.

3. The remoteness of mountains helped to preserve a high cultural diversity.

4. Mountain ecosystems are exceptionally fragile.

5. Mountains are water towers of the world.

6. Mountains often represent political borders, restrict transport to narrow corridors, and are refuges for minorities.

7. Recreation and tourism.

8. In general, poverty and vulnerability of people is higher in mountain regions than elsewhere.

(Source: S. Eva and K. Christian, "Global Mountain Biodiversity Assessment"2005)

\section{The way forward to conserve the mountain biodiversity}

* Better integration into broader development and poverty reduction strategies and greater coherence and synergies among sectoral responses

* More systematic consideration of tradeoffs among ecosystem services

* More equitable and fair access to and sharing of ecosystem services

* Small scale agriculture in densely populated mountain areas where the establishment or extension of protected areas is not feasible

* Payment for environmental services (PES) to compensate upland users for the lack of on-site benefits by the people living in lowlands

* Equity and gender issues and empowerment of grass roots women and organizational development

* Awareness and consciousness among the local residents in regards to the importance of its biodiversity conservation and community based activity for participatory conservation of it

* Alternative livelihood opportunities through the diversification of farming systems for those who are dependent on forest resources

* Trans-boundary cooperation and measures for prevailing illegal poaching and illegal transboundary trading of the wildlife

* Buffer zone establishment and land use planning

* GIS and RS application and establishing a database of nature reserves 


\section{Conclusion}

Mountains cover almost one fourth of the Earth's surface and host about one tenth of the global population. Mountains are among the most fragile environment on earth, but, at the same time, due to their diverse vegetation and varied microclimatic and ecological conditions, they have high levels of biodiversity and provide a number of very important ecological functions. Thus these functions have contributed to human well being well beyond the immediate vicinity, benefiting entire river basins. As a result, mountains have been referred to as "natural water towers "as well as the spectacular scenery, the many rare and endangered plant and animal species, highly complex socio-ecological systems, with rich cultural diversity and local handicrafts help to make it key destination sites.

Biodiversity is the key of life on earth: human existence - with food, medicines, fibers, fuel, building materials, and many other facets of what we know as civilization - was only able to evolve because of biodiversity related ecosystem services. Mountains are not only remarkably diverse but also important globally as centers of biological diversity as it supports approximately one quarter of terrestrial biological diversity, with nearly half of all 34 world's biodiversity hotspots concentrated in it.

Mountain biodiversity plays a key role in the support of global environmental, economic, social and cultural sectors through its connections to invasive species, air pollution, climate change, mining, hydropower, tourism, forests, agriculture and thus help in the overall development. In spite of the greatest value of mountains the biodiversity is now threatened by human actions, globalization and climate change. Hence, proper management of mountain resources is inevitable for the socio-economic development of the mountain people, their respective country and the world as a whole.

\section{Reference}

Barthlott, W., Lauer, W. and Placke, A. 1996. Global distribution of species diversity in vascular plants: Towards a world map of phytodiversity. Erdkunde 50:317327

Becker, A. and Bugman, H. 1999. Global Change and Mountain Regions IGBP, Stockholm, Sweden.

Gotame, B. 2008. Economics of Biodiversity Conservation in Nepal. The Initiation 2:55-61.

Djohlaf, A. 2009. Biodiversity Conservation and Management for Enhanced Ecosystem Services responding to the challenges of Global Change, 4(1-5).

Guangwei chen, 2002."Participatory biodiversity conservation in the Hindu Kush-Himalayan Ecoregion", Biodiversity in the Eastern Himalayas, ICIMOD, Kathmandu, Nepal, 3-9. 
Hamilton, S. and Bruijnzeel, L. A. 1997. Mountain watersheds-integrating water, soils, gravity, vegetation, and people. In:Messerli, B. and Ives, J.D. (eds.), Mountains of the world - a global priority. The Parthenon Publishing Group, 337-370.

Körner, C., Spehn E., Messerli B. 2001. Mountain Biodiversity Matters. The Swiss Academy of Sciences, Bern, Switzerland in cooperation with The United Nations University.

Korner, C. 2004, Mountain Biodiveristy, its causes and function. Ambio Special Report 13:11-17.

Korner, C. 2009. Conservation of Mountain Biodiversity in the Context of Climate Change. Proceedings of the International Mountain Biodiversity Conference, Sharma Eklabya, ICIMOD, Kathmandu, Nepal ,21-33.

Messerli, B. and Ives, J. D. (eds.), 1997. Mountain of the World: A Global Priority. Tha Parthenon Publishing Group.

NBS. 2002. Nepal Biodiversity Strategy. Ministry of Forest and Soil Conservation, Kathmandu, Nepal.

Robert, Z. 2009. Acknowldeging the Contribution of Mountain Communities-Investing in the Future. Biodiversity and Climate Change in the Himalayas, Sustainable Mountain Development. No.55 ICIMOD, Spring 2009, 10-15.

Schild, A. 2009. Regional Research on Biodiversity: Improved Knowledge as a Basis for Better Livelihoods", Biodiversity and Climate Change in the Himalayas, Sustainable Mountain Development. No.55 ICIMOD, Spring 2009, 10-15.

Science for Environment Policy, 2006. In http://ec.europa.eu/environment/integration/ research/newslater/pdf/21na1.pdf

Sharma, E. 2009. Mountain Biodiversity: The region's greatest resource. Mountain Biodiversity and Climate Change. ICIMOD.

Sharma, E. 2009.The need for long-term research and action in the Hindu Kush-Himalayas. Mountain Biodiversity and Climate Change, ICIMOD.

Sharma, E. and Karma, T. 2009.Climate Change in the Himalayas: the Vulnerability of Biodiversity. Biodiversity and Climate Change in the Himalayas, Sustainable Mountain Development. No.55. ICIMOD, Spring 2009, 10-15.

Sharma, E., Karma T., Chettri N. and Shrestha A. 2009. In Biodiversity in the Himalayas - Trends, Perceptions, and Impacts of Climate Change, proceedings of ICIMOD, Kathmandu, Nepal, 40-53.

Shrestha, A., Devkota B., L P. 2008. Climate change: Case studies of Eastern Himalayan region and Brahmaputra and Koshi basins. With paper prepared for assessment of climate change vulnerability of the mountain ecosystems of the Eastern Himalayas. ICIMOD-MacArthur Project (final draft). 
Spehn, E. and Körner, C. 2009. "Mountain Biodiversity -A Global Heritage" Mountain Forum Bulletin July 2009.

Spehn, E. and Körner, C. 2005. "Global Mountain Biodiversity Assessment", Global Mountain Biodiversity Assessment of DIVERSITAS. Basel, Switzerland.

Thompson, C. 2009. The Eastern Himalayas Where Worlds Collide. WWF, Kathmandu, Nepal 2.

$\mathrm{http} / / / \mathrm{www}$. fao.org/mnts/archive/2006/intl_mountain_note_en.asp

http://www.cbd.int/mountain/about.shtml

http://www.biodiversityhotspots.org/xp/hotspots/hotspotsscience/key_findings/Pages/ default.aspx

http://www.cnrs.fr/inee/recherche/fichiers/_Biodiversite_hotspots.pdf

$\mathrm{http} / / /$ www.nepalmonitor.com/2009/08/a_living_himalayas_3.html 